\title{
Regulators and villains: the dual role of private actors in diamonds and caviar
}

\section{Dina Siegel ${ }^{1} \cdot$ Toine Spapens $^{2} \cdot$ Daan van Uhm $^{1}$}

Published online: 20 June 2020

(C) The Author(s) 2020

\begin{abstract}
In the past decades, private actors have become key actors in regulation and enforcement of various forms of trade. In this paper, we focus on the role of private actors in the regulation of the trade in diamonds and caviar. We examine the stages of calling for additional regulation; setting regulatory requirements; and determining and effectuating compliance mechanisms. Our analysis illustrates that private actors may play important roles in this process, but at the same time be unaware of loopholes that illegal operators may exploit, whereas others may commit crimes themselves. These dual roles reflect the various activities of private actors in different representations. We argue in this article that the increased involvement of private actors in processes of regulation may not only benefit but also constrain the effectivity, competence and meaning of such regulatory frameworks within contemporary society.
\end{abstract}

\section{Introduction}

Regulation of corporate activities may be viewed as a continuum that ranges from no restrictions to full prohibition. In practice, in territories governed effectively by sovereign states, few corporate activities are either fully prohibited or fully unregulated. Almost always basic regulations must be met with to ensure the safety of customers, personnel, the public, the environment as well as to protect the integrity of economic activities, financial institutions and the government. However, those who design regulatory laws are usually not primarily interested in crime prevention or

Daan van Uhm

d.p.vanuhm@uu.nl

Dina Siegel

dina.s@uu.nl

Toine Spapens

a.c.spapens@tilburguniversity.edu

1 Utrecht University, Utrecht, The Netherlands

2 Tilburg University, Tilburg, The Netherlands 
enforceability. Although criminologists have written extensively on this topic, the academic fields of regulation and governance and criminology have increasingly diverged in recent years, with corporate criminology largely disappearing from the debate on regulation and governance [1]. Yet, criminological study of processes of regulation and governance remains highly important. On the one hand, this concerns critical assessment of the policy makers' assumption that a process of decriminalization and regulation will 'automatically' reduce the size of criminal markets, whereas in fact it may also create new illegal opportunities [2]. On the other, it is necessary to understand better the criminogenic effects of tightened regulation, also in the context of adequate enforcement. In the past decades, processes of regulation and deregulation have increasingly shifted from a command and control approach in which governments largely determined the outcomes and took responsibility for enforcement, to a process of co-production in which private actors play crucial roles in drawing up the rules and ensuring compliance. However, from a corporate crime perspective, it is clear that private parties may not just act as efficient and trustful partners.

In this article, we address the roles of private actors in the tightening of regulation of the diamond and caviar markets. The findings are based on original empirical research and literature-based research. Siegel revisited her original fieldwork on the diamond trade [3] and Van Uhm his original fieldwork on illegal caviar [4] in order to examine the dual role of private actors in the illicit trade in diamonds and caviar. Data collection for the diamond study took place in 2003-2007 in Antwerp, Belgium and the caviar study was executed in March and September 2014 in Russia. The authors conducted semi-structured interviews to tap into the various modi operandi of illegal entrepreneurs, including private actors such as corporations involved in the diamond and caviar markets.

Section "Regulation, governance and corporate crime" first presents a brief overview of recent developments in the academic debate on regulation and enforcement, and the roles of private actors in the process, and formulates a framework of analysis based on the three main stages of regulation and enforcement. Section "Private actors and the process of regulating conflict diamonds and caviar" describes the role of private actors and the tightening of regulation of the diamond and caviar markets. Section "Analysis of the role of private actors in the regulatory process" reflects upon the role of private actors in calls for increased regulation, in drawing up regulations and in compliance and control mechanisms. Section "Discussion and conclusion" concludes this paper with a discussion and conclusion.

\section{Regulation, governance and corporate crime}

During the past four decades, designing effective regulations has become increasingly complex. Academics first attributed this to a speeding up of the process of globalization, particularly after the fall of the Iron Curtain [5]. The development of the Internet further accelerated globalization of information streams and transboundary trade. Second, the ongoing process of technical modernisation caused dramatic changes to western culture and produced a 'risk society'[6]. This increasingly resulted in a need to control social, political, ecological and individual risks. Third, the dominant paradigm of neo-liberalism vastly increased feelings of uncertainty regarding vital human needs. This too is reflected in a desire to minimise the risk of any sort of harm imaginable, either real or perceived 
[7]. Although advocates of neoliberalism have continuously called for deregulation, in fact the opposite has occurred [8,9]. Indeed, the free market ideology requires all sorts of regulations to keep markets fair and competitive, and to facilitate safety measures [7].

Increased complexities resulted in rethinking the process of regulating corporate activities and approaches to enforcement and compliance. Instrumental, state centric and law-focused command and control concepts of regulation were increasingly viewed as flawed, and replaced by a concept of 'governance without government' [10-12]. A single nation state was no longer able to regulate cross-border matters effectively. Theories of regulation traditionally concerned a dyadic relationship between state agencies and private actors, usually corporations [13]. Although regulation operates as an instrument of governmental control, its main goal was often to benefit the industry [14]. Influenced by globalization, regulation theory was expanded with concepts such as 'reflexive' and 'responsive' regulation (e.g. $[15,16])$ and 'regulatory regimes' [17] to allow better regulation by broadening the set of available instruments and focusing on broader actor constellations. In addition, governance theories gradually replaced traditional concepts of social steering with ideas of co-operation, negotiation, co-production, hybrid communication, self-regulation and networks [13]. Governance theory does however not essentially differ from regulation theory: the aim remains to influence societal behavior, albeit more indirectly.

In the context of enforcement, Ayres and Braithwaite [8] translated their ideas of responsive regulation into the famous 'enforcement pyramid' which has been hugely influential albeit also viewed as too simplistic (e.g. [18]). Furthermore, influenced by neo-liberalism concepts of self-regulation were implemented in a range of corporate activities, although these have strongly declined in popularity, especially after the financial crisis of 2008 [13]. By comparison, governance theory focuses more on hybrid procedures and arrangements, instead of on hierarchical models of control. In sum, theories of regulation and governance have in common a shift to cooperation; application of multiple instruments for intervention, such as power, money, law information and public opinion; and indirect forms of control, including soft law and reflexive law, and governance [13].

From a criminological viewpoint, shifts towards co-production and including different private actors in the regulatory process may be regarded as positive as well as negative. Increased transparency and including citizens and societal interest groups in it, may result in better outcomes. Indeed, powerful societal actors have always tried to influence such processes and allowing others to engage structurally in this process may assure a more level playing field. Negatively, private actors may be less able to 'think as a criminal' when designing regulations and thus leave loopholes, and they may be less aware of issues of enforceability. In addition, private actors may lack integrity themselves. This is shown in an extensive literature on crimes of the powerful that highlights the dangerous role private actors can play in defining, regulating and controlling crime (e.g. [19-21]). Tillman [20] presents an overview of situations in which private actors helped to make the rules, but were also responsible for first line enforcement. He concludes that these markets are particularly vulnerable to corporate misconduct.

The various roles of private actors in the process of regulation may be distinguished in three stages, outlined in Fig. 1, which we will apply as a framework of analysis in the two case studies discussed in the next section. 


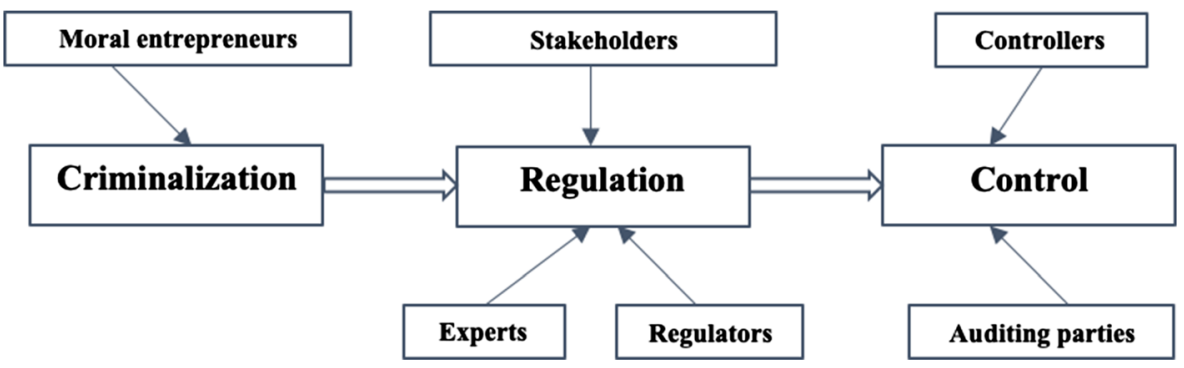

Fig. 1 Various roles of private actors

In the first stage, actors try to reframe existing regulations. Actors involved may be individual citizens - for instance via social media - scientists, traditional media, corporate lobbyists and NGOs, at the local, national and international levels. The targeted activities, may be considered increasingly harmful and require further restrictions or even full prohibition. The new frame may also be that existing restrictions no longer serve the intended purpose and should be deregulated. The process of definition setting is never fully objective: socially and economically powerful groups in society are better placed to successfully call for additional regulation or deregulation, than less powerful actors ([22]: 480-481).

In the second stage of the process, regulations are drawn up. In a command and control approach to regulation, this would be the prerogative of government institutions. In practice, however, other stakeholders lobby to protect their interests. In the Netherlands for example, it was revealed several years ago that banks had been 'helping' the government even to word legislation in terms that enabled them to avoid extra taxes [23]. As explained above, defining regulations is increasingly a process of co-production between different stakeholders in which different private actors and the authorities set the conditions, restrictions and proceedings by balancing social, economic and environmental interests [24-26].

In the third stage, actors design and effectuate compliance mechanisms. This for instance involves policy makers consulting enforcement agencies, but here too private actors increasingly participate in this process, particularly when self-regulation mechanisms are considered.

\section{Private actors and the process of regulating conflict diamonds and caviar}

We applied the framework above to assess the role of private actors in the process of regulation of the trade in diamonds and caviar. This section describes the results.

\section{Conflict diamonds}

The diamond industry has historically been secretive and isolated. Diamond traders across the world created their own semi-autonomous organization. They set their own rules and codes of behavior; shared common values and norms, and applied social control and justice mechanisms. All of this emphasized the value of their product and 
offered protection against external threats. Business disputes, for example, were resolved internally according to sets of rules and sanctions, complete with distinctive institutions set up by sophisticated traders who dominated the industry ([27]: 115).

These mechanisms helped to guarantee survival of the diamond industry in difficult periods, independent from local authorities. Until today the actors rely on a system of mutual trust and face to face relationships, spanning worldwide networks, markets and institutions, but more recently also on advanced technology and closer cooperation with state agencies [27-29]. Informal bonds, customs, and institutions developed in the course of history separately from society and legal systems and served predominantly to guard the diamond traders' reputation. However, at the end of the twentieth and the beginning of the twenty-first century, the problem of so-called 'blood' or 'conflict diamonds' shook generations-long traditions and internal dynamics.

The issue appeared on the international agenda at the end of the 1990s when dramatic reports came from Sierra Leone about rebels cutting off limbs and torturing powerless civilians who dared to oppose them. In addition, evidence from Angola and Liberia showed deportations, rapes, killings and confiscations of land and property. Several human rights organizations described these atrocities as related to 'conflict diamonds.' Rivalry over the control of diamond mining was considered one of the sources of the violence and the proceeds of the diamond trade were allegedly fueling the civil wars. As a result more than seventy NGOs, including Global Witness, Partnership Africa Canada, Medico International, NIZA, Human Rights Watch and Amnesty International quickly succeeded in placing the topic of 'conflict diamonds' high on the international political agenda.

Several prominent diamond traders (i.e. De Beers), issued a policy statement of zero tolerance for 'blood diamonds' trade ([30]: 389). It resulted in regulations to control the transnational flow of diamonds known as the Kimberley Process (see Box 1.1). The process was concluded in May 2000 and in 2002, supported by a resolution of the UN General Assembly, fifty-two nations had adopted the Kimberley Process Certification Scheme (KPCS).

\footnotetext{
Box 1.1 Regulating diamonds: the Kimberley Process

The Kimberley Process (KP) is a joint governmental, industry and civil society initiative to stem the flow of conflict diamonds - defined as rough diamonds used by rebel movements to finance wars against legitimate governments. Participation is, however, voluntary (KPCS: sVI, para 8). Participants should first and foremost ban all trade in rough diamonds with non-participants, whether import or export (KPCS: sIII (c)). Second, trading States must ensure that each shipment of rough diamonds on export (KPCS sII (a)) and on import (KPCS: sIII (b)) is accompanied by a Kimberley Process Certificate.

The Kimberley Process Certificate is a document with a particular format which identifies a shipment of rough diamonds as being in compliance with the requirements of the Certification Scheme (KPCS: sI). The Certificate must be readily accessible for a period of no less than three years (KPCS: sIII (b) alinea 3) and there are duties to inform the exporting participant of a confirmation of a Certificate which confirmation includes details about the transaction (KPCS: sIII (b) alinea 2).

Each Participant should establish a system of internal controls designed to eliminate the presence of conflict diamonds from shipments of rough diamonds imported into and exported from its territory (KPCS: sIV (a)). States are obligated, as required, to amend or enact appropriate laws or regulations to implement and enforce the Certification Scheme and to maintain dissuasive and proportional penalties for transgressions (KPCS: sIV (d)).
}

In 2002, the EU adopted Regulation 2368/2002 to implement the KPCS. It subjected import and export of diamonds to a certification scheme. However, the Regulation does 
not apply to diamond trade between the Member States, because of the basic principle of the freedom of movement of goods. Hence, the role of the private actor, namely, the diamond industry, and specifically its self-regulation mechanisms, became of prominent importance to prevent smuggling within the EU. Diamond traders are expected to certify all conflict-free diamonds for internal or external sale and thus ensure compliance with the KPCS.

The Kimberley Process was initially hailed as a successful effort to better regulate the trade through existing transnational social relationships and interests at the international level as well as international institutions and with a prominent role for private actors. However, evaluation reports soon also raised doubts about its efficiency [31, 32]. For example, only a few percent of annual diamond production originated from conflict zones. Why then should diamond traders across the world comply with costly KPCS regulations, even if they did not do any business with countries in African conflict zones? Second, the countries where diamonds were mined often lacked enforcement capabilities to combat fraud, corruption and the smuggling of diamonds [33]. Furthermore, the KPCS did not regulate transports of conflict diamonds. If law enforcement agencies are unable to enforce compliance, who is? Can private actors, such as mining multinationals prevent criminal activities at the mines and at the borders? Third, under the existing import control system it is difficult to determine whether diamonds originate from conflict zones. Conflict diamonds may for instance be laundered by mixing them with non-conflict diamonds. Finally, 'non-conflict' African countries such as Botswana complained openly about the damaging effect of KPCS regulations on their reputation and economy.

The Kimberley process does not set standards to prevent unsafe and unhealthy working conditions and environmental harm. However, the greatest paradox was that Western consumers were discouraged from purchasing 'blood diamonds' on the one hand, while on the other the human rights issue was almost forgotten. Another major problem in conflict zones was that because of the KPCS's strict regulation artisan diggers and their families as well as small companies lost their only source of income. These communities can be considered as victims of both ethnic conflicts and local violence in their countries, and of far-reaching interventions by regulations and laws imposed by the West ([34]: 9).

The KPCS has shown to be vulnerable to fraud. One example is the Monstrey investigation, which started in October 2005. Monstrey Worldwide Services, a shipping firm, was accused of fraud, which took the form of 'black trade', when legally imported diamonds were fictively exported abroad, but in reality, remained in Antwerp. In connection to this case, the Belgian police started an investigation in the Antwerp diamond district in January 2007, which resulted in the closure of 20 diamond firms. It transpired that suspected companies had not declared profits, failed to pay VAT and had falsified account books. More than 150 diamond companies were involved in this fraud, which the Belgian federal police estimated at more than 100 million euros.

\section{Black caviar}

The second case that illustrates the dual role of private actors is the trade in black caviar. Regulations date back to the tsars of Russia when official documents for fishing in the Caspian Sea were required and only a few traders obtained a license for tax-free 
fishing [35]. In Soviet times, the Communist regime exclusively owned all fishing rights in the Caspian Sea and quota limits for sturgeon applied, certain fishing gear was prohibited and foreign entrepreneurs were banned from sturgeon fishery [36, 37]. The authorities closely monitored fishery and outlawed sturgeon fishing in the Caspian Sea as early as 1962 to maintain a balanced population [38]. The Soviet authorities centralized production under a strict state monopoly, comparable to how De Beers protected its diamond mines [3].

After the dissolution of the Soviet Union, the authorities privatized the caviar trade and abolished existing management and control systems. This political transformation and privatization offered opportunities for large-scale poaching of sturgeons [39, 40]. Due to the impact of resulting overexploitation and unsustainable harvesting, ${ }^{1}$ under pressure from environmental groups, such as NGOs, all sturgeon species were included in the Appendices of the Convention on International Trade in Endangered Species (CITES) [41, 42] (See Box 1.2). ${ }^{2}$ Since 1998, all international shipments of caviar must be accompanied by CITES permits. ${ }^{3}$

\begin{abstract}
Box 1.2 Regulating caviar: CITES
CITES is an international treaty, currently signed by 183 governments, that regulates the trade in wild animal and plant species or products thereof through CITES permits. The export of sturgeons included in Appendix II requires the prior grant and presentation of an export permit (CITES: Art. IV (2)). A separate permit is required for each consignment of specimens (CITES: Art. VI (5)). A specimen is also a derivative of a specimen; e.g. eggs in case of caviar (CITES: Art. I (b) (II).

An export permit must contain information about the specimens demanded by the treaty (CITES: Appendix IV) and may only be used for export within a period of six months from the date on which it was granted (CITES: Art. VI (2)). In addition, the treaty prescribes formal requirements to the permits and certificates (CITES: Art. VI (3)). There are nation and region-specific export quotas. Regarding the Caspian Sea region, there exists a Commission for Aquatic Bio resources of the Caspian Sea, which sets quotas, the TAC (Total Allowable Catch).
\end{abstract}

The European Union implemented CITES in Council Regulation (EC) No 338/97 of 9 December 1996. Similar to the diamond trade, the principle of free movement of goods applies within the EU [43].

While CITES is known to be the most important instrument for regulating the trade in protected wildlife, there is little empirical evidence that restrictive measures help to prevent overexploitation. According to Hutton and Dickson [44] CITES is often unable to regulate the trade in CITES species successfully. In practice, it is often impossible to meet with the condition that the trade will not put the survival of the particular species at risk and, consequently, such species have become even more endangered [45]. Several CITES II species have therefore been elevated to CITES I.

\footnotetext{
${ }^{1}$ The most important species of sturgeon for caviar production are the Beluga (Huso huso), the Russian Sturgeon for (Acipenser gueldenstaedtii) and the Sevruga for (Acipenser stellatus). The production from these species accounts for about $80 \%$ of all caviar trade ([39]: 774).

${ }^{2}$ All species have been listed in the Appendices of CITES, including two species listed in Appendix I (EC 338/97, Annex A), which prohibits the commercial trade in wild species. The international caviar trade of Appendix II species (EC 338/97, Annex B) is only allowed when shipments are accompanied by the appropriate CITES permits, issued by the relevant national CITES Management Authorities (Oldfield 2003; European Commission 2010).

${ }^{3}$ With the exception of a maximum amount of $125 \mathrm{~g}$ of caviar per person to be used for non-commercial purposes.
} 
In the case of sturgeon fishing, large amounts of illegal catches drove populations to the edge of extinction. In 2001, the CITES Committee threatened, during its forty-fifth meeting in Paris, to impose a complete export ban on caviar for the countries around the Caspian Sea, unless "they implemente[d] a series of time-sensitive measures designed to stem the alarming depletion of sturgeon stocks in the region" ([46]: 13). While the restrictions had a substantial impact on the local economy, it was not enough to protect the populations of sturgeons. Therefore, Russia completely banned wild sturgeon harvesting and all Caspian countries joined this ban [47, 48].

However, CITES-regulations still offered loopholes to private trading enterprises. They for example, used CITES certificates to acquire an import license for a shipment of legal caviar; sent half of it back, and reused the import license to sell illegal caviar [49]. Another method is falsification, for instance of CITES documents; of the labels of caviar tins by imitating well-known brands; or of documents on the country of origin or the company [50]. Corrupt local CITES authorities may also provide documents to launder illegal caviar. CITES allows trade in captive bred animals, and thus illegal wild caviar may be sold as having been grown in fish farms [50]. Finally, it is possible to fish for sturgeons under scientific quota, which also provides criminal opportunities. ${ }^{4}$ Statistical data covering several years after the ban demonstrates that a lot of sturgeons were caught in the Caspian Sea for 'scientific purposes' [51].

In response to illegal practices, several caviar traders have signed the World Wide Fund for Nature's (WWF) 'Code of Conduct' on sturgeon protection. Parties agree to follow the 'best business practices' in addition to existing national, EU and international legislation. The Code is a self-regulation tool that 'aims to improve the companies' transparency and increase their reputation with customers, institutions and investors'. Although the document is not legally binding, environmental NGOs see it as a first step to involve private business actors in protecting sturgeons from illegal caviar trafficking (e.g. [52]).

\section{Analysis of the role of private actors in the regulatory process}

In this section, we apply the three-stage framework to further analyze the diamond and caviar cases.

\section{Stage 1: Calling for additional regulation}

Both in the cases of diamonds and caviar, private actors played an important role in calling for additional regulation. In the 1990s several environmental NGOs (e.g. WWF and TRAFFIC) drew international attention to the illegal trade in caviar and its effect on the Caspian ecosystem, while in the 1990s and 2000s human rights NGOs (e.g. Global Witness) pushed governments to take action to regulate the trade in conflict diamonds.

\footnotetext{
${ }^{4}$ Although fishing sturgeons in the Caspian Sea is illegal, there are exceptions to fish on sturgeon for scientific purposes, e.g. to investigate the conditions of the wild sturgeons in order to monitor the wild population of sturgeon. 
Already in 1994, the Human Rights Watch's Angola Report accused De Beers a prominent trading company, and several trading states, such as Belgium, of collaborative activities with Angolan rebels. "The De Beers diamond cartel and other international dealers are buying gems mined in rebel-held territory in violation of Angolan law (...) Diamonds sales enable UNITA to pay for weapons, as well as oil and lubricants, obtained in violation of international sanctions" ([53]: 62). Several years later, in 1998, the Human Rights Watch's report 'A Rough Trade', provided further evidence on issues concerning the trade in blood diamonds [54]. Other NGOs, such as the Canadian Sierra Leone Working Group, corroborated the evidence and in the late 1990s the Netherlands Institute for Southern Africa, Global Witness and the German NGO Medico International started their "fatal transaction" campaign, informing about the situation in Angola, Cambodia, Congo, Liberia and other countries [55].

Several environmental NGOs, such as WWF and TRAFFIC, underlined also the scale of unregulated caviar trafficking and the need for international regulation in the late 1990s (e.g. [40]). Although commercial trade in caviar was prohibited under the Regulations for the Protection of Fish Stocks approved by the Russian government, the sturgeon population in the Caspian Sea continued to decrease and this caused much concern. NGOs argued that "control over export, import, and reexport of sturgeons and their derivatives according to CITES provisions must be performed" ([40]: 18). Urged by several environmental groups, all sturgeon species were included in the Appendices of the Convention on International Trade in Endangered Species (CITES) [42]. We conclude that NGOs in their role of moral entrepreneurs successfully called for deterrence, suppression, and punishment of harmful activities.

\section{Stage 2: Setting regulatory requirements}

During the second stage of the regulatory process, in which legislation is drawn up private actors are increasingly involved in co-designing provisions and standards together with government agencies. The process may include different types of actors, such as the government, law enforcement, and a variety of private parties in roles of stakeholder, expert or regulator. Although it is a co-production between different actors, powerful economic actors may have a dominant impact on the outcome of the process. Corporations involved in the diamond and caviar businesses were indeed influential in how regulations were formulated and were criticized because of their sided interests.

The Kimberley Process resulted in an industry-based certification scheme enclosed in an export-import regime that was implemented in national legislation by the EU Member States. Private actors played a prominent role in designing and implementing the rules and standards [56]. The voluntary regulatory system can be seen as a variant of 'civil regulation' that has appeared across many sectors in recent years (e.g. [57]). During the plenary meetings, various civil society organizations took part in the process of decision making. According to observers they exerted a 'significant influence in the implementation of policies through their expertise, knowledge, and reputation for serving public rather than private interests' ([58]: 12). Moreover, NGOs such as Global Witness and PAC acted as 
experts and observers in the Kimberley Process; they provided reports and information and participated in negotiations. ${ }^{5}$

Private actors also provided information and assistance during CITES meetings about caviar. For example, in 1999, TRAFFIC and the CITES committee signed a memorandum of understanding to undertake joint activities in capacity building. TRAFFIC is a partnership between the WWF and the International Union for Conservation of Nature (IUCN). Together with the IUCN, TRAFFIC publishes in-depth analyses of all formal CITES proposals put forward by Parties to be discussed at the Conference of the Parties (CoP). TRAFFIC publishes its recommendations on each decision to be taken (e.g. with respect to which appendix a species should be placed in), based on the results of these analyses. Private actors, including caviar traders and NGOs, also offer expertise regarding policies and regulations. For instance, the NGO, the International Association for Danube Research (IAD), accumulated much taxonomic expertise and developed strategies for improving policies (e.g. [59]). Other initiatives such as the International Sturgeons Symposium (including CITES, IUCN, IWMC, CEP, TRAFFIC, and many others) influence policy making and conservation of sturgeons ([60]: 1).

The above shows that private actors may exert substantial influence on the process of drawing up regulations. In the case-studies presented above, these were 'independent actors' who judged what was wrong and right; what are conflict or non-conflict diamonds; and what is wild or captive bred caviar. In practice, regulations were often impossible to implement and the parties largely ignored potential negative consequences for the local population in terms of loss of work and income, as well as the fact that tightening of regulations could create new opportunities for criminal entrepreneurs.

\section{Stage 3: The role of private actors in compliance mechanisms}

The diamond and caviar cases show that private actors also played an important role in establishing and operating control mechanisms. Since the early 2000s, the diamond industry began to implement a voluntary system of certification and established internal controls to prevent distributions of conflict diamonds [56]. Under the KPCS, all participant states are required to ensure that diamond imports and exports are properly certified and do not originate from non-member states. This state-based border control system was complemented by industry self-regulation which "will provide for a system of warranties underpinned through verification by independent auditors of individual companies and supported by internal penalties set by industry, which will help to facilitate the full traceability of rough diamond transactions by government authorities" (KPSC supra note 366, Section IV). Each trading company is obliged to keep records of the warranty invoices when buying or selling diamonds. These flows must be audited and reconciled by the company's own auditors each year. Global Witness and Amnesty International highlight that companies have to go beyond these industry standards and implement third-party auditing measures to make the warranty system credible and effective [61].

In the caviar case several companies signed the 'Code of Conduct' drawn up by the WWF, which illustrates cooperation between NGOs and the private sector in the

\footnotetext{
${ }^{5}$ For instance, the Global Witness report "For a Few Dollars More: How Al Qaeda Moved into the Diamond Trade" influenced the policies of Kimberley Process.
} 
development of self-regulation tools to aim for 'best business practices' in the caviar trade. This code of conduct is an official commitment of the industry against illegal sourcing of wild sturgeons and wild caviar. The WWF highlights that the code aims to improve the transparency of the companies and simultaneously increases the companies' reputation with customers, institutions and investors. One of the commitments that the companies made was to inform customers of the benefits of CITES labels that make caviar production traceable [52].

\section{Discussion and conclusion}

The discourse on semi-autonomous social and legal fields in postmodern society provides some analytical tools for better understanding the dual role of private actors in regulated economic activities, as described in the cases above. In these semiautonomous fields, private actors are aware of their rights, obligations and codes of behavior in such a way that they 'can make law its custom' ([62]: 744). The relevant question is whether and how these semi-autonomous legal and social fields can explain the dynamic of internal (self)regulations and interrelationships inside the community on the one hand, and the continuously changing relations with the outside world on the other. It is extremely difficult to be isolated and immune from the influences from the 'outside': growing mobility, increasing levels of risks and threats, as well as new mechanisms of control. The presence of private actors in every aspect of our lives is 'so overbearing that it makes it seem as if this presence is both normal and natural' ([63]: 2; [64]). Therefore, members of these communities need to be creative in their response to the changing relations with public and other private actors.

In this paper we analyzed the role of private actors in legislative arrangements and enforcement regimes by looking at the trade in diamonds and caviar. Besides for setting regulatory standards and preventing crime, private actors may also use their powerful influence for criminal purposes. Here we have highlighted this dual role. Big scandals in both the diamond and caviar industry have proved the discrepancy between the legal and empirical reality of implementation. Firstly, it is difficult to determine the origin of diamonds and caviar: conflict or non-conflict, wild or captive bred, legal or illegal [3, 4]. Private actors are aware of these sensitivities in the regulatory frameworks which offer loopholes to manipulate or launder conflict diamonds and illegal caviar into perfectly legal products [65].

Secondly, the social role of control and auditing parties may be vulnerable to corrupt activities as is for instance illustrated by catching sturgeons in the Caspian Sea for 'scientific purposes'. Indeed, Tillman [20], Blake et al. [66] and others underline that the culture of organizational corruption is widespread and may influence the effectiveness of regulatory frameworks. Private actors cannot only influence the wording of regulations in their role of stakeholders, experts and legitimizers (e.g. [55]), they may also, simultaneously, benefit from (under)developed forms of self-regulation.

Thirdly, in the context of self-regulation industry representatives are regularly operating as official observers. In the KPCS framework sanctioning of parties in response to identified issues by audits is not clearly established. These control systems developed by the industry and audited by company's own auditors reflect the sided interests and opportunities for dodgy activities and agreements. Moreover, members can profit from the 'assured market, free of sanctions or legal repercussions for market transactions' ([56]: 98). 
Thus, based on our findings the existing conceptualization of private actors as bonafide trustful actors is too narrow. On the one hand, private actors are able to define the good and the bad: the costs of excluding others are relatively low, while the benefits of being a participant may be high because of the influence on processes. On the other hand, they can misuse their powerful positions to hide illegal activities. With continuously changing relations with the outside world, these private actors are aware of their rights, obligations and codes of behavior in such a way that some of these actors can manipulate their position by influencing regulation, customizing laws, implementing control mechanisms, but also committing crimes without being noticed.

Thus, the increasing influence of private actors may in some cases offer inventive solutions to close existing gaps in regulation and enforcement [67]. However, in other cases business models and economic incentives may threaten the rule of law. Patterns of internal arbitrage, secrecy, double standards, unofficial obligatory settings can be found in various legitimate sectors, as shown on the examples of the diamond and caviar industry. In those cases, we see how these legitimate sectors can employ moral strategies to make profits and widen their markets. In other words, preferences of private regulation or enforcement over public law arrangements provide new criminal opportunities that are concealed behind such hybrid arrangements. In contrast to the positive role of private actors in regulation and enforcement, we tried to warn in this article that there are also possible negative consequences. We argue that the increased involvement of private actors may not only benefit but also constrain the effectivity, competence and meaning of such regulatory frameworks within contemporary society.

Open Access This article is licensed under a Creative Commons Attribution 4.0 International License, which permits use, sharing, adaptation, distribution and reproduction in any medium or format, as long as you give appropriate credit to the original author(s) and the source, provide a link to the Creative Commons licence, and indicate if changes were made. The images or other third party material in this article are included in the article's Creative Commons licence, unless indicated otherwise in a credit line to the material. If material is not included in the article's Creative Commons licence and your intended use is not permitted by statutory regulation or exceeds the permitted use, you will need to obtain permission directly from the copyright holder. To view a copy of this licence, visit http://creativecommons.org/licenses/by/4.0/.

\section{References}

1. Almond, P., \& Erp, van, J. (2018). Regulation and governance versus criminology: Disciplinary divides, intersections, and opportunities. Regulation and Governance, 14, 167-183. https://doi.org/10.1111 /rego.12202.

2. Spapens, T. (2012). The question of regulating illegal markets. The gambling and cannabis markets in the Netherlands. GSTF Journal of Law and Social Sciences, 2(1), 30-37.

3. Siegel, D. (2009). The mazzel ritual. New York: Springer.

4. Van Uhm, D. P. (2016). The illegal wildlife trade: Inside the world of poachers. Springer International: Smugglers and Traders.

5. Braithwaite, J., \& Drahos, P. (2000). Global business regulation. Cambridge: Cambridge University Press.

6. Beck, U. (1992). Risk society: Towards a new modernity. London: Sage.

7. Ericson, R. (2007). Crime in an insecure world. Cambridge: Polity Press.

8. Ayres, I., \& Braithwaite, J. (1992). Responsive regulation: Transcending the deregulation debate. New York: Oxford University Press.

9. Power, M. (2004). The risk management of everything. In The risk management of everything: Rethinking the politics of uncertainty. London: Demos. 
10. Paul, R. \& Mölders, M. (2017). Introduction: Society regulation and governance: new modes of shaping social change? In: Paul, R. Mölders, M., Bora, A., Huber, M. \& Münte, P. Society, regulation and governance. Cheltenham: Edward Elgar Publishing, 1-11.

11. Paul, R., Mölders, M., Bora, A., Huber, M., \& Münte, P. (2017). Society, regulation and governance. Cheltenham: Edward Elgar Publishing.

12. Rhodes, R. (1996). The new governance: Governing without government. Political Studies, 44(4), 652667.

13. Bora, A. (2017). Semantics of ruling: Reflective theories on regulation, governance and law. In:

14. Baldwin, R., Cave, M., \& Lodge, M. (2013). Understanding regulation: Theory, strategy and practice (2nd ed.). Oxford: Oxford University Press.

15. Braithwaite, J. (2006). Responsive regulation and developing economies. World Development, 34, 884 898.

16. Braithwaite, J. (2011). The essence of responsive regulation. Fasken lecture, UBC Law Review, 44(3), 475-520.

17. Hood, C., Rothstein, H., \& Baldwin, R. (2001). The government of risk: Understanding risk regulation regimes. Oxford: Oxford University Press.

18. Scott, C. (2012). Regulating everything: From mega- to meta-regulation. Administration, 60(1), 61-89.

19. Barak, G. (2015). The crimes of the powerful and the globalization of crime. Revista Brasileira de Direito, 11(2), 104-114.

20. Tillman, R. (2009). Making the rules and breaking the rules: The political origins of corporate corruption in the new economy. Crime, Law and Social Change, 51, 73-86.

21. Tombs, S., \& Whyte, D. (2003). Unmasking the crimes of the powerful. Critical Criminology, 11, 217236.

22. Nadelmann, E. A. (1990). Global prohibition regimes: The evolution of norms in international society. International Organization, 44, 479-526.

23. Giebels, R. (2015). Banken wijzen minder kredietaanvragen af. Volkskrant, (22 July 2015).

24. Huisman, W., \& van Erp, J. (2013). Opportunities for environmental crime: A test of situational crime prevention theory. British Journal of Criminology, 53(6), 1178-1200.

25. King, A., \& Toffel, M. (2009). Environmental governance and political science. In Delmas \& O. Young (Eds.), Governing the environment: interdisciplinary perspectives. Cambridge: Cambridge University Press.

26. Palazzo, G., \& Scherer, A. G. (2006). Corporate legitimacy as deliberation: A communicative framework. Journal of Business Ethics, 66(1), 71-88.

27. Bernstein, L. (1992). Opting out of the legal system: Extralegal contractual relations in the diamond industry. The Journal of Legal Studies, 21(1992), 115-157.

28. Dickinson, J. (1965). The book of Daimonds: Their history and romance from ancient India to modern times. New York: Avenel Books.

29. Legrand, J. (1985). Diamant: Mythe, Magie en Werkelijkheid. Brussel/Amsterdam: Elsevier.

30. Morton, J. S. (2005). The legal regulation of conflict diamonds. Politics \& Policy, 33(3), 389-414.

31. Peleman, J. (2002). Conflictdiamanten - gezien vanuit Afrika. Tijdschrift voor Criminologie, 44, 358366.

32. Belgische Senaat. (2002). Parlementaire onderzoekscommissie 'Grote Meren'. Hoorzittingen, Verslag, Vrijdag 11 januari 2002, gr. 7.

33. Government Accounting Office. (2002). International trade: Critical issues remain in deterring conflict diamond trade, GAO-02-678. Washington DC.

34. Easterly, W. (2007). The white man's burden: Why the West's efforts to aid the rest have done so much ill and so little good. London: Penguin.

35. Saffron, I. (2002). Caviar. The strange history and uncertain future of the. World's Most Coveted Delicacy: New York, Broadway Books.

36. Birstein, V. J., Bemis, W. E., \& Waldman, J. R. (1997). The threatened status of acipenseriform species: A summary. In V. J. Birstein, W. E. Bemis, \& J. R. Waldman (Eds.), Sturgeon biodiversity and conservation (pp. 427-435). Dordrecht: Springer Netherlands.

37. Raymakers, C. (2002). Study on the social and economic aspects of illegal fishing in the Caspian Sea. Traffic Europe: Brussels.

38. Ruban, G. I., \& Khodorevskaya, R. P. (2010). Caspian Sea sturgeon fishery: A historic overview. Journal of Applied Ichthyology, 27, 199-208.

39. Birstein, V. J., Doukakis, P., Sorkin, B., \& DeSalle, R. (1998). Population aggregation analysis of three caviar-producing species of sturgeons and implications for the species identification of black caviar. Conservation Biology, 12, 766-775. 
40. Vaisman, A. (1997). Sturgeon catch and trade in the Russian part of the Caspian Sea. Traffic Europe: Brussels.

41. Bronzi, P., Rosenthal, H., \& Gessner, J. (2011). Global sturgeon aquaculture production: An overview. Journal of Applied Ichthyology, 27, 169-175.

42. Raymakers, C. (2006). CITES, the convention on international trade in endangered species of wild Fauna and Flora: Its role in the conservation of Acipenseriformes. Journal of Applied Ichthyology, 22, 53-65.

43. Van Spaandonk, J. A. M. (2000). Katern CITES. Toelichting op de Overeenkomst inzake de internationale handel in bedreigde in het wild levende dier-en plantensoorten. Lelystad: Koninklijke Vermande.

44. Hutton, J., \& Dickson, B. (Eds.). (2000). Endangered species, threatened convention: The past, present, and future of CITES, the convention on international trade in endangered species of wild Fauna and Flora. London: Earthscan.

45. Jenkins, R. W. (2002). 'The significant trade process: Making appendix II work' in endangered species threatened convention: The past, present and future of CITES, the convention on international trade in endangered species of wild Fauna and Flora. London: Earthscan.

46. Gordon, M. (2002). Such stuff as dreams are made on: The story of caviar, from prehistory to the present. Harvard: Harvard University.

47. Douglas, F. (2012). USA: Reducing illegal wildlife trafficking-CITES and caviar. Environmental Policy and law, 42-57.

48. Nellemann, C., Henriksen, R., Raxter, P., Ash, N., \& Mrema, E. (Eds.). (2014). The environmental crime crisis - Threats to sustainable development from illegal exploitation and trade in wildlife and Forest resources. United Nations Environment Programme and GRID-Arendal: A UNEP Rapid Response Assessment Nairobi and Arendal.

49. Knapp, A., Kitschke, C., \& von Meibom, S. (Eds.). (2006). Proceedings of the international sturgeon enforcement workshop to combat illegal trade in caviar. Brussels: Traffic: Prepared by TRAFFIC Europe for the European Commission.

50. Van Uhm, D. P., \& Siegel, D. (2016). The illegal trade in black caviar. Trends in Organized Crime, 19(1), 67-87.

51. Zabyelina, Y. G. (2014). The 'fishy' business: A qualitative analysis of the illicit market in black caviar. Trends in Organized Crime, 17, 181-198.

52. WWF (2015). Sturgeon aquaculture farms commit to protect sturgeons. WWF.

53. Human Rights Watch (1994). Angola: Arms trade and violations of the Laws of war since the 1992 elections. Washington: Human Rights Watch.

54. Human Rights Watch (1998). A rough trade: The role of companies and governments in the Angolan conflict. Washington: Human Rights Watch.

55. Bieri, F. (2010). Roles of NGOs in the Kimberley process. Globality Studies Journal, 10(2010).

56. Haufler, V. (2009). The Kimberley process, club goods, and public enforcement of a private regime. Voluntary Programs: A Club Theory Perspective, 89(2009).

57. Ruggie, J. G. (2004). Reconstituting the global public domain-Issues, actors, and practices. European Journal of International Relations, 10(4), 499-531.

58. Bieri, F. (2016). From blood diamonds to the Kimberley process: How NGOs cleaned up the global diamond industry. New York: Routledge.

59. Bloesch, J. (2009). The International Association for Danube Research (IAD)_Portrait of a transboundary scientific NGO. Environmental Science and Pollution Research, 16, 116-122.

60. Rosenthal, H., Pourkazem, M., \& Bruch, R. (2006). The 5th international symposium on sturgeons: A conference with major emphasis on conservation, environmental mitigation and sustainable use of the sturgeon resources. Journal of Applied Ichthyology, 22, 1-4.

61. Global Witness and Amnesty International. (2007). Conflict diamonds. London: Global Witness and Amnesty International.

62. Moore, S. F. (1973). Law and social change: The semi-autonomous social field as an appropriate subject of study. Law \& Society Review, 7, 719-746.

63. Tombs, S., \& Whyte, D. (2015). Counterblast: Crime, harm and the state-corporate nexus. Howard Journal of Criminal Justice, 54(1), 91-95.

64. Garland, D. (2002). The culture of control. Crime and social order in contemporary society. Oxford: Oxford University Press.

65. Van Uhm, D. P. (2018). Wildlife and laundering: interaction between the under and upper world. In T. Spapens, R. White, D. Van Uhm, \& W. Huisman (Eds.), Green crimes and dirty money. London: Routledge. 
66. Blake, A., Gioia, D., Robinson, S. L., \& Trevino, L. K. (2008). Re-viewing organizational corruption. Academy of Management Review, 33(3), 670-684.

67. White, R. (2012). NGO engagement in environmental law enforcement: Critical reflections. Australasian Policing, 4(1), 7-11.

Publisher's note Springer Nature remains neutral with regard to jurisdictional claims in published maps and institutional affiliations. 